\title{
The United Kingdom and Central Europe: A Dream of an Alternative
}

\author{
Adam Hudek
}

For centuries, Central Europe was shaped by German economic, cultural and intellectual influence. Each 'Western import', whether intellectual or technological, usually reached the region through German channels. The representatives of the small nations in the German dominated Mitteleuropa acknowledged certain positive aspects of this influence. However, they were also constantly looking for ways to counterbalance it. The fear of German encroachment is still today one of the basic building blocks of the shared identity of Central European countries. The crucial point of the historical development of Central Europe in the last 200 years is the effort to break or resist the German hegemony.

In the nineteenth and early twentieth centuries the Anglophilia present among intellectuals and politicians in Central Europe was one way to break from this German dominance. It was an effort to go directly to the centre of European modernity, liberalism and democracy, and not just wait for what would arrive through the 'German filter'. The United Kingdom was seen as one of the few possible counterbalances to German power and influence over the region. Even at the beginning of the twenty-first century, the UK's approach to EU integration offered an alternative to the federal structures of the German dominated European Union. The focus of this essay is to place the UK's role and image in Central Europe in historical perspective and offer an historically informed hypothesis on the future influences of the Brexit referendum that took place in 2016. By referring predominantly to the Czech and Slovak cases, it will show the complexity but also continuity of a natural alliance with the UK.

In 1924 Karel Čapek, a well-known Czech intellectual and close friend of the first Czechoslovak president, Tomáš Garrigue Masaryk, published his impression from his trip to Great Britain under the title 'English Letters' (for him, England and the United Kingdom were synonyms). In the concluding essay he stated:

In all places where political democracy is present, there is a part of the English symbolic territory. . . . Everywhere on this planet, where the ideals of personal freedom, dignity, respect towards individuality and inviolability of human rights are in effect, there is a cultural heritage of England, and you are not looking on a foreign land, but on a 'greater England' which is a home of the majority of the civilised people.' (Karel Čapek, Anglické listy, Praha 1934, 149)

For Čapek, interwar Czechoslovakia constituted a natural part of this 'symbolic territory'. Like many of his contemporaries, he was convinced that if his country was in danger, the UK would help, not only because of existing pacts but also because of the UK's moral commitment to protect democratic states.

Čapek's friend Masaryk was also strongly oriented towards the Anglo-Saxon world. When the United States withdrew from European affairs after 1918 he hoped that the UK would sustain a permanent political presence in Central Europe. Such hopes went unfulfilled as the United Kingdom left the region to France. Anglophiles in Czechoslovakia were then even more baffled and disappointed when diplomatic activities and interventions of various British actors were not

(c) Cambridge University Press 2019. 
always in favour of Czechoslovakia. In 1938 people like Čapek were devastatied to hear Neville Chamberlain talking about not going to war 'because of a quarrel in a faraway country between people of whom we know nothing', as an explanation as to why he would sign the Munich Agreement, which left Czechoslovakia to the mercy of Nazi Germany.

For the Czechoslovak intellectuals of the interwar era the UK became an elusive superpower with largely incomprehensible objectives. Čapek wrote that 'England' differed from continental Europe in every possible aspect: from grass to parliament and universities. In 1936 another famous Czech intellectual and journalist, Ferdinand Peroutka, published an article titled 'Mysterious England'. In this piece he tried to explain the peculiarities of the British lifestyle and politics to the Czechoslovak audience. The title alone illustrated the contemporary image of the $\mathrm{UK}$ in the region.

Although British politicians were never particularly interested in Central Europe, their sporadic actions were always of great significance. On important occasions, the UK, like a deus ex machina, intervened in the matters of the Czechs and Slovaks and other central European nations only to withdraw again after a short time. Its role was crucial to the process of reshuffling Central Europe after 1918; without British consent, the Czechoslovak state could never have been established. However, twenty years later the politics of appeasement contributed to its destruction.

Similar scenarios continued to repeat themselves. During the Second World War British help was crucial for the renewal of Czechoslovakia as a democratic state. The UK was the first state to reject the validity of the Munich Agreement, and the Czechoslovak exile government resided in London throughout the war. Despite this, according to Central European historical memory, Winston Churchill enabled Stalin to take control over Central Europe when they met to discuss the division of Europe into spheres of influence in October 1944. The general British impression of the Cold War was then aptly - and from Central European point of view cynically - described by the British foreign secretary Douglas Hurd, after its conclusion in December 1989, as 'a system ... under which we've lived quite happily for forty years'.

However, this statement manifested only the attitude of official politics. In the second half of the twentieth century the UK was no longer a 'mysterious country' for the people of Czechoslovakia. The cultural and intellectual influence of the Anglo-Saxon world grew stronger even on the socialist side of the Iron Curtain. Although official UK policies did not intervene in the internal matters of the socialist countries, the UK maintained significant cultural and intellectual presence in the region. Anglo-Saxon pop culture had a profound impact on young people throughout Central Europe. The UK became one of the most popular safe havens for the anticommunist exiles, including the author of the 'Mysterious England', Ferdinand Peroutka. During the 1970s conservative philosopher Roger Scruton became part of the 'underground university' in Prague, organising seminars for the dissidents. At the same time, young Czech and Slovak economists eagerly studied recent UK economic developments. From the 1980s on Thatcherite conservatism (together with Reaganism) had a profound impact on Czechoslovak dissenters, and on scholars in the social sciences. Britain's rather unintentional soft power made it nearly as popular as the United States in the stagnating Central European communist states. The vitality of the Anglo-Saxon word became a desired alternative to the grey life in 'real socialism'.

After the fall of communism, the UK became a strong advocate of the quick integration of Central Europe into Western international structures. In her last year as prime minister Margaret Thatcher supported the efforts of the post-communist Central European states to join the EU because she considered them 'Britain's natural allies'. It was a reasonable assumption, since the UK already had an influential group of supporters in these countries. In Czechoslovakia, proBritish sympathies were clearly visible. The Minister of Finance (future Czech prime minister and president), Václav Klaus, was a self-described Thatcherite, while the Czechoslovak president Václav Havel suggested, albeit without success, to adopt the UK electoral system. The young generation of economists leading the transformation of the post-communist states towards a market economy saw the UK as a role model: a successful, modern, rich, individualist society. In 
their eyes it was the exact opposite to not only the communist economy but also the apparently inflexible continental models based on the endless compromises. British as well as American politicians and academics were the first to open their universities and think tanks to young talent from Central Europe on a large scale, creating the next generation of influential supporters.

When speaking about 'natural allies' in Central Europe, the British political elite saw the UK as the informal leader and defender of the smaller states, sceptical about visons of closer European integration. British politics in this matter provided an alternative to the 'end of history' of the fully integrated Europe in the German and French plans. British diplomats expected that their historical experiences had made Central European countries - especially new ones like Slovakia - suspicious towards models that now limited their national sovereignty. They also knew that the British neoliberal advocacy for the European single market and competitiveness was popular among influential policymakers in the post-communist states. The UK thus became a symbol of an alternative to the dominant political developments in the EU. It provided a counter-narrative to the rebels, those critics of EU development and opponents to its allegedly socialist economic politics and drive towards stronger integration. Like a hundred years earlier, cooperation with the UK was seen as an alternative to, or even necessary step against, the growing German economic dominance in the so-called Visegrad Group (V4) countries, the Czech Republic, Hungary, Poland and Slovakia.

Contrary to the situation at the beginning of the twentieth century, though, this time a hope for a stronger UK presence in Central Europe had a rational core. In 2004, immediately after the V4 countries joined the EU, the UK government made a crucial decision which fundamentally changed the relations between the UK and the post-communist Central European countries. Long before any of the other significant EU states, the UK opened its job market to the new EU members. As a result, within a few years, British (and Irish) companies became the target destinations for significant numbers of Central Europeans. This step effectively helped to solve the crushing problem of unemployment in countries such as Slovakia and Poland. While Germany was the top investor, the UK became the number one employer in the V4 region. Through the mass migration of hundreds of thousands of people, the UK became inextricably involved with the region. The traditional politics of withdrawal thus became much more complicated than before, not least because this time, UK also needed allies in Europe more than ever. The UK siphoned the spare workforce from V4, and parts of the UK economy became dependent on these people.

Paradoxically, the UK became a victim of its success in Central Europe. The opening of the UK job market for its Central European allies turned out to be one of the key arguments in the pro-Brexit campaign. 'Yes' for leaving the EU can be thus seen as a popular demand to abandon the active involvement with Central Europe adopted after 1989, to break the ties with the people 'of whom we know nothing'. However, as various analysts and political experts have pointed out, the process of withdrawal will be significantly more complicated than it has been on earlier occasions. This time, Central Europeans will have their say about the conditions of the UK exit. The V4 countries are members of the EU and will co-decide the final form of Brexit. The Polish and Slovak prime ministers already openly stated that the agreement must be in favor of their citizens working in the UK. Paradoxically, this stance makes these states important British allies in the struggle against a no-deal Brexit. In short, despite the desires of the Brexiteers to forget about Central Europe, its states remain 'Britain's natural allies', and their requirements have to be acknowledged in the negotiation process.

In the increasingly Eurosceptic V4, where Germany generally invokes little sympathy, the current British critique of the $\mathrm{EU}$ is instead viewed with open understanding. Contrary to countries of the 'EU core', the humiliation of the UK in the Brexit process is, therefore, not in the interest of V4, for all the historical connections discussed in this essay. In the context of an exceptionally close and growingly unpopular integration of V4 countries into the German economy, political representatives of these countries will look for a counterbalance, just as their 
predecessors had done. On the basis of such a historical perspective, the following hypothesis seems reasonable: the 'British alternative', which provided Central European countries with support for resisting German dominance in the EU in its various forms, will survive. Despite Brexit, the overall image and influence of the UK in Central Europe can very possibly remain unchanged, both in the general population and among political elites. 